\title{
Karakteristik Peternak dan Dukungan Penyuluhan dalam Mendukung Kemampuan Manajerial Beternak Sapi Potong di Desa Oepuah Utara
}

Agustinus Efua ${ }^{a}$ dan Ture Simamora ${ }^{b}$

aFakultas Pertanian, Universitas Timor, Kefamenanu, TTU - NTT, Indonesia. Email: agustinusefu98@gmial.com

bFakultas Pertanian, Universitas Timor, Kefamenanu, TTU-NTT, Indonesia. Email: turesimamora@rocketmail.com

\section{Article Info}

Article history:

Received 23 Desember 2020

Received in revised form 30 Desember 2020

Accepted 18 Januari 2021

DOI:

https: / /doi.org/10.32938/ag.v6i1.1229

Keywords:

Farmer Characteristics

Livestock Extension

Managerial Ability

\begin{abstract}
Abstrak
The character of the farmer is something that lies in the nature that is contained in a person when someone implements and has courage. The purpose of this study was to analyze how the influence of breeders and livestock extension support on improving the managerial ability of beef cattle in North Oepuah Village, Biboki Monleu District, North Central Timor Regency. The type of research used is the sampling method carried out by purposive sampling. Data collection was carried out using a questionnaire. The results showed the influence of breeders and extension support on the managerial ability of raising beef cattle in North Oepuah Village, namely education, training intensity, appropriateness of extension methods.
\end{abstract}

\section{Pendahuluan}

Karakteristik merupakan sesuatu yang menyangkut sifat yang terdapat dalam diri seseorang ketika melaksanakan dan mengelola usahanya (Risma, 2012). Karakteristik peternak meliputi umur, tingkat pendidikan dan pengalaman memiliki korelasi terhadap pengelolaan usaha sapi potong. Menurut Baba et al., (2011) penyuluhan merupakan salah satu unsur penting dalam peningkatan usaha pertanian/peternakan. Pemanfaatan sumber informasi melalui penyuluhan diyakani memberikan manfaar dalam menyelesaikan masalah yang dihadapi. Dengan demikian dukungan penyuluhan peternakan tentu dibutuhkan dalam mendukung kegiatan usaha peternakan sapi potong. Dukungan penyuluhan peternakan akan berimplikasi terhadap perubahan perilaku peternak melalui peningkatan pengetahuan, sikap dan keterampilan.

Penyuluhan adalah cara untuk mengubah perilaku seseorang agar mau dan mampu mengelola usahanya secara profesional dan optimal. Perubahan perilaku yang dimaksud merupakan perubaha yang terjadi melalui proses pendidikan sehingga orang tersebut menjadi lebih produktif (better farming), mampu meningkatkan pendapatan (better business) serta mampu meningkatkan kesejahteraan hidupnya (better living). Penyuluhan peternakan yang berhasil sangat erat kaitannya dengan kesesuaian media, metode dan kemampuan teknis penyuluh. Metode penyuluhan yang dilaksanakan dengan pendekatan kelompok akan memberikan dampak yang lebih signifikan dan menguntungkan bagi sasaran penyuluhan. Pendekatan kelompok dalam kegiatan penyuluhan akan mengefektifkan interaksi kelompok serta memberikan kesempatan komunikasi timbal balik antara penyuluh dan sasaran penyuluhan.

Peternakan sapi potong yang dikembangkan oleh masyarakat biasanya terbentuk dengan peranan kelompok peternak. Besarnya peranan kelompok dalam pengembangan usaha peternakan di pedesaan menjadikan pendekatan penyuluhan secara berkelompok menjadi sangat tepat dilakukan. Menurut Muslim (2006) perlu pengembangan usaha pertanian/peternakan dengan membina kelompok tani ternak serta meningkatkan perananan kelembagaan pertanian secara berkelanjutan. Pengembangan usaha peternakan sapi potong di pedesaan menjadi penting dilakukan dengan mengoptimalkan peranan penyuluhan terhadap kelompok peternak. Menurut Lestari et al., (2017) perlu perbaikan setiap subsistem peternakan sapi potong, oleh karena itu perlu kebijakan pemerintah dalam mendukung pengembangan sapi potong di Indonesia.

Peternakan sapi potong di pedesaan menjadi salah satu sumber perekonomian di masyarakat. Simamora (2020) menyatakan peternakan sapi potong yang dikelola secara baik akan memberikan pendapatan dan peningkatan kesejahteraan. Usaha peternakan sapi potong akan berhasil bila mampu memberikan kontribusi bagi peningkatan sumber pendapatan keluarga. Dengan demikian perlu kemampuan manajerial dalam mengelola usaha sapi potong sehingga memberikan hasil atau keuntungan yang optimal. Peternak sapi potong di dorong memiliki kemampuan manajerial yang baik. Kemampuan manajerial adalah keterampilan yang dimiiliki oleh peternak sapi potong dalam merencanakan usaha hingga memasarkan hasil usaha.

Desa Oepuah Utara merupakan salah satu desa basis peternakan sapi potong. Pemeliharaan sapi potong di desa tersebut sudah berlangsung lama. Oleh karena itu, perlu dilakukan penelitian terkait karakteristik dan dukungan penyuluhan terhadap kemampuan manajerial sapi potong di Desa Oepuah Utara. 


\section{Metode}

Penelitian dilakukan pada Bulan Oktober 2019 di Desa Oepuah Utara, Kecamatan Biboki Monleu, Kabupaten Timor Tengah Utara. Penentuan lokasi penelitian ini dilakukan secara sengaja dengan alasan bahwa daerah tersebut merupakan daerah peternakan sapi potong yang tergabung dalam binaan gabungan kelompok tani oleh Dinas Peternakan Kabupaten Timor Tengah Utara. Adapun populasi penelitian ini adalah seluruh peternak sapi potong yang berada di Desa Oepuah Utara dan aktif tergabung dalam kelompok tani sebanyak 30 orang. Seluruh populasi dijadikan sampel dengan pertimbangan jumlah populasi tersebut relatif sedikit. Data penelitian dikumpulkan melalui pengajuan pertanyaan (kuisioner) kepada peternak. Data yang dikumpulkan dalam penelitian ini berupa data kuantitif dengan didukung dengan data kualitatif yang diperoleh ketika wawancara dengan peternak di lokasi penelitian.

Adapun sumber data penelitian ini adalah data primer dan data sekunder. Data primer diperoleh langsung dari responden penelitian. Data sekunder diperoleh dari Dinas Peternakan Timor Tengah Utara. Data yang telah dikumpulkan kemudian ditabulasi dan dianalisis secara deskriptif dan infrensial. Analisis data deskriptif digambarkan melalui persentase sedangkan analisis infrensial dilakukan melalui SPSS.

\section{Hasil dan Pembahasan}

3.1. Karakteristik Peternak Sapi Potong

Karakteristik peternak sapi potong adalah keseluruhan ciri yang terdapat dalam diri peternak dan berimplikasi terhadap kegiatan usahanya. Karakteristik adalah bagian diri yang telah melekat pada diri seseorang sejak lahir. Adapun karakteristik peternak yang diteliti dalam penelitian ini yaitu umur, pendidikan, pengalaman dan intensitas pelatihan. Simamora dan Luik (2019) menyatakan karakteristik merupakan salah satu faktor penting penentu keberhasilan usaha. Hasil penelitian terkait karakteristik peternak sapi potong di Desa Oepuah disajikan pada Tabel 1.

Tabel 1. Karakteristik Peternak Sapi Potong di desa Oepuah Utara

\begin{tabular}{lcc}
\hline \multicolumn{1}{c}{ Kategori } & $\begin{array}{c}\text { Jumlah Responden } \\
\text { (orang) }\end{array}$ & $\begin{array}{c}\text { Presentase } \\
(\%)\end{array}$ \\
\hline Umur (tahun) & 8 & 26,7 \\
$\quad$ Sangat Muda (21-29) & 12 & 40 \\
Muda (30-45) & 6 & 20 \\
Sedang (46-55) & 4 & 13,3 \\
Tua (56-65) & & \\
Pendidikan Formal & 27 & 90 \\
$\quad$ Tamat SD & 1 & 3,3 \\
Tamat SMP & 1 & 3,3 \\
Tamat SMA & 1 & 3,3 \\
Tamat PT & 17 & 56,7 \\
Pengalaman Beternak & 9 & 30 \\
$\quad$ Rendah (1-3) & 4 & 13,3 \\
$\quad$ Sedang (4-7) & & \\
Tinggi (8-11) & 22 & 73,3 \\
Intensitas Pelatihan & 5 & 16,7 \\
$\quad$ Sangat Rendah (2-12) & 1 & 6,7 \\
Rendah (13-23) & 2 & 6,7 \\
$\quad$ Sedang (24-34) & &
\end{tabular}

Umur peternak merupakan salah satu faktor yang memberikan pengaruh terhadap tingkat kemampuan fisik peternak dalam mengelola usahanya (Simamora et al.,2015). Menurut Suwarta et al., (2012) peternak yang semakin tua akan berpengaruh terhadap penurunan produktivitas peternakan sapi potong. Hal lain yang berhubungan dengan umur peternak adalah kemampuan dalam mengadopsi inovasi. Peternak yang sudah tua akan lebih lambat dalam mengaplikasin inovasi-inovasi pengembangan sapi potong. Hal ini dipengaruhi oleh berkurangnya kekuatan fisik dan pemikiran untuk cepat tanggap dalam merespon setiap inovasi peternakan. Hasil penelitian Ma'sum et al.,(2013) menunjukkan karakteristik umur, pendidikan, dan pengalaman peternak sapi potong berpengaruh pada penerapan inovasi inseminasi buatan.

Tingkat pendidikan yang dimiliki peternak juga memiliki dampak terhadap kemampuan berpikir untuk pengembangan usaha sapi potong. Tingkat pendidikan adalah lama dan jenjang pendidikan formal yang ditempuh peternak. Semakin tinggi tingkat pendidikan seseorang maka 
akan membentuk kematangan pikiran dan perilaku serta kemampuan dalam pengambilan keputusan. Dengan demikian tingkat pendidikan berdampak pada kemampuan peternak dalam mengelola usaha sapi potong.

Pengalaman beternak merupakan salah satu karakteristik yang bisa mempengaruhi keberhasilan usaha sapi potong. Pengalaman beternak adalah lamanya peternak menekuni usaha peternakan tersebut. Hasil penelitian Hermawan et al.,(2017) menjelaskan pengalaman usaha adalah gambaran kemampuan manajerial usaha. Berdasarkan pengalaman yang dimiliki peternak semakin mampu mengatasi permasalahan dan menciptakan peluang pengembangan usaha. Tingat pengalaman beternak dan intensitas pelatihan akan semakin meningkatkan kemampuan peternak dalam mengelola usaha sapi potong. Pengalaman beternak yang cukup lama memberikan indikasi bahwa pengetahuan dan keterampilan beternak dan manajemen pemeliharaan ternak yang dimiliki petani semakin baik. Hasil penelitian Damihartini dan Jahi (2005) menujukkan pengetahuan dan keterampilan agribisnis yang harus dikuasai memiliki hubungan positif terhadap agribisnis yang diusahakan

Intensitas pelatihan adalah banyaknya pelatihan terkait sapi potong yang diikuti oleh peternak. Pelatihan terkait peternakan sapi potong akan semakin meningkatkan keterampilan dari peternak. Pelatihan peternakan memuat informasi, teknik dan praktek beternak sapi potong secara baik. Keberhasilan pelatihan peternakan sangat erat kaitannya dengan persepsi peternak tersebut terhadap materi pelatihan dan inovasi yang ditawarkan. Rogers (2003) menyatakan bahwa persepsi adalah penilaian awal terhadap suatu informasi atau inovasi.

\subsection{Dukungan Penyuluhan}

Penyuluhan peternakan bisa terlaksana dengan baik apabila didukung oleh media, metode, dan materi yang sesuai dengan masalah sasaran penyuluhan. Beberapa indikator dukungan penyuluhan antara lain (1) kesesuaian metode, (2) kesesusaian materi, (3) kesesusaian media dan (4) kompetensi penyuluhan. Hasil penelitian terkait dukungan penyuluhan terhadap peternak sapi potong di Desa Oepuah Utara disajikan pada Tabel 2.

Tabel 2. Dukungan Penyuluhan Peternakan Sapi Potong di Desa Oepuah Utara

\begin{tabular}{llcc}
\hline \multirow{2}{*}{ Aspek Dukungan } & \multicolumn{1}{c}{ Kategori } & $\begin{array}{c}\text { Jumlah Responden } \\
\text { (orang) }\end{array}$ & Presentasi (\%) \\
\hline Kesusaian Metode & Tidak Tahu & 2 & 6.7 \\
& Tidak Mangerti & 0 & 0 \\
& Cukup mengerti & 15 & 50 \\
& Mengerti & 13 & 43.3 \\
Kesesuaian Materi & Tidak Tahu & 3 & 10 \\
& Tidak Sesuai & 6 & 20 \\
& Cukup Sesuai & 7 & 23.3 \\
Kesesuaian Media & Sesuai & 14 & 46.7 \\
& Tidak Mengerti & 15 & 50 \\
& Cukup Mengerti & 8 & 26.7 \\
Kompetensi Penyuluhan & Mengerti & 7 & 23.3 \\
& Tidak Setuju & 0 & 0 \\
& Kurang Setuju & 0 & 0 \\
& Setuju & 19 & 63.3 \\
& Sangat Setuju & 11 & 36.7 \\
\hline
\end{tabular}

Sumber: Diolah dari data primer, 2020.

Berdasarkan hasil penelitian aspek kesesuaian metode penyuluhan terhadap pengembangan peternakan sapi potong di Desa Oepuah Utara mengambarkan kategori dominan cukup mengerti. Hal ini mengindikasikan bahwa metode penyuluhan yang dipakai selama melakukan kegiatan penyuluhan sesuai dengan keadaan peternak dan bisa dimengerti. Materi penyuluhan peternakan sapi potong juga dirasakan telah sesuai dengan masalah dan kebutuhan peternak. Adapun media yang digunakan dalam kegiatan penyuluhan bisa dimengerti peternak dengan baik. Media penyuluhan haruslah sesuai kondisi dan kebutuhan sasaran penyuluhan. Kompetensi penyuluh dinilai kompeten ketika melaksanakan kegiatan penyuluhan peternakan sapi potong. Menurut Anwas (2011) kompetensi penyuluh sangat dibutuhkan dalam kegiatan penyuluhan. Kompetensi penyuluh yang baik dideskripsikan dari pengetahuan, sikap dan keterampilan dalam membina sasaran penyuluhan. Hasil penelitian Rahmawati et al.,(2016) menunjukkan bahwa peran, kinerja dan inovasi penyuluh berpengaruh secara langsung dan signfikan terhadap keberdayaan peternak. 


\subsection{Kemampuan Manajerial}

Kemampuan manajerial sapi potong merupakan tindakan peternak yang mampu mengelola usaha sapi potong secara baik. Kemampuan manajerial peternak dicerminkan dari perilaku mulai dari kemampuan merencanakan usaha hingga kemampuan dalam memasarkan hasil usaha sapi potong. Kemampuan manajerial sapi potong adalah salah satu kunci keberhasilan pembangunan sumber daya peternakan. Tingkat kemampuan manajerial diukur berdasarkan kemampuan dalam menyusun perencanaan usaha dan kemampuan membuat pencatatan usaha. Adapun hasil penelitian terkait kemampuan manajerial sapi potong di Desa Oepuah disajikan pada Tabel 3.

Tabel 3. Kemampuan Manajerial Peternak Sapi Potong

\begin{tabular}{ccc}
\hline Kategori & $\begin{array}{c}\text { Jumlah Responden } \\
\text { (orang) }\end{array}$ & $\begin{array}{c}\text { Presentase } \\
(\%)\end{array}$ \\
\hline Rendah & 14 & 46,7 \\
Sedang & 13 & 43,3 \\
Tinggi & 3 & 10 \\
\hline
\end{tabular}

Sumber: data dari data primer,2020

Hasil penelitian menunjukkan bahwa kemampuan manajerial peternakan sapi potong di Desa Oepuah dominan tergolong rendah. Hal ini tentu dipengaruhi oleh rendahnya kemampuan peternak sapi potong dalam membuat perencanaan usaha, rendahnya kemampuan dalam membuat perencanaan keuangan serta rendahnya kemampuan dalam memasarkan sapi potong dengan harga bersaing. Simamora (2020) menyatakan kompetensi peternak merupakan kunci keberhasilan pembangunan sapi potong.

\subsection{Pengaruh Karakteristik Peternak dan Dukungan penyuluhan Terhadap Kompetensi Manajerial}

Untuk mengetahui pengaruh antara karakteristik peternak dan dukungan penyuluhan terhadap kemampuan manajerial di Desa Oepuah Utara digunakan analisis regresi berganda. Analisis ini merupakan suatu analisis yang dapat mengukur seberapa besar pengaruh antara karakteristik peternak dan dukungan penyuluhan terhadap kompetensi manajerial beternak sapi potong di Desa Oepuah Utara. Adapun hasil analisis regresi disajikan pada Tabel 4.

Tabel 4. Nilai Koefisien Determinasi

$\begin{array}{ccccc}\text { Model } & \mathrm{R} & \mathrm{R} \text { Square } & \text { Adjusted R Square } & \begin{array}{c}\text { Std. Error of the } \\ \text { Estimate }\end{array} \\ 1 . & .690 \mathrm{a} & .476 & .277 & .25454\end{array}$

a. Predictors: (Constant), Dukungan Kompetensi, Karakteristik Umur, Dukungan Metode, Dukungan Media, Karakteristik Pendidikan, Karakteristik Intensitas, Karakteristik Pengalaman, Dukungan Materi.

b. Dependent Variable: Kompetensi Manajerial.

Berdasarkan hasil analisis regresi linier berganda diperoleh nilai koefisien regresi (r) sebesar 0.690. Hal ini menunjukkan terdapat hubungan yang positif dan erat antara karakteristik peternak, dukungan penyuluhan terhadap kemampuan manajerial. Koefisien determinasi $\left(\mathrm{R}^{2}\right)$ sebesar 0.476 memberi pengertian bahwa besarnya tingkat pengaruh karakteristik peternak, dukungan penyuluhan terhadap kemampuan manajerial sebesar $47.6 \%$, dan selebihnya $52.4 \%$ adalah faktor lain yang tidak diteliti. Hasil penelitian Oktavia et al.,(2019) menyatakan dukungan penyuluhan atau program pembinaan seperti Sekolah Peternakan Rakyat mampu meningkatkan kemampuan peternak dalam akses penjualan yang lebih luas dibandingkan dengan peternak yang tidak mendapatkan pembinaan dan peningkatan nilai tambah peternak peserta program SPR dapat dilihat dari peningkatan bobot sapi.

\section{Simpulan}

Berdasarkan hasil penelitian, maka disimpulkan bahwa karakteristik umur peternak di Desa Oepuah Utara bervariasi dengan didominasi peternak umur produktif sebesar 40 persen. Tingkat pendidikan peternak didominasi peternak berpendidikan SD. Pengalaman beternak sapi potong didominasi pengalaman rendah. Dukungan penyuluhan dengan indikator kesesuaian metode memiliki nilai paling besar di kategori cukup mengerti. Indikator kesesuaian materi penyuluhan didominasi dengan kategori sesuai. Indikator kesesuaian media penyuluhan didominasi dengan kategori tidak mengerti. Indikator kompetensi penyuluhan didominasi dengan kategori setuju. Kemampuan manajerial didominasi kategori rendah. Pengaruh antara krakteristik peternak dan 
dukungan penyuluhan terhadap kemampuan manajerial beternak sapi potong di Desa Oepuah Utara adalah Pendidikan, intensitas pelatihan, kesusaian metode dan kompetensi penyuluh.

\section{Pustaka}

Anwas OM. 2011. Membangun Media Massa Publik dalam Menanamkan Pendidikan Karakter. Jurnal Pendidikan Dan Kebudayaan 17(6), 680-690.

Damihartini RS, Jahi A. 2005. Hubungan Karakteristik Petani Dengan Kompetensi Agribisnis Pada Usahatani Sayuran Di Kabupaten Kediri Jawa Timur. Jurnal Penyuluhan, 1(1). https://doi.org/10.25015/penyuluhan.v1i1.2097.

Hermawan A, Amanah S, Fatchiya A. 2017. Partisipasi Pembudidaya Ikan dalam Kelompok Usaha Akuakultur di Kabupaten Tasikmalaya, Jawa Barat. Jurnal Penyuluhan. 13(1): 1-13.

Lestari RD, Baga LM, Nurmalina R. 2017. Daya saing usaha penggemukan sapi potong peternakan rakyat di Kabupaten Bojonegoro, Jawa Timur. Buletin Peternakan 41: 101-112.

Ma'sum M, Hubeis AVS, Saleh A, Saharjo B. 2013. Hubungan Antara Karakteristik Internal dan Eksternal Peternak Sapi Potong dan Adopsi Inovasi Inseminasi Buatan. Jurnal Penyuluhan 9 (1). https://doi.org/10.25015/penyuluhan.v9i1.9859.

Muslim. 2006. Panduan Lengkap Sapi Potong. Penebar Swadaya, Jakarta.

Oktavia HC, Cahyadi ER, Syamsun M. 2019. Peran Sekolah Peternakan Rakyat dalam Meningkatkan Nilai Tambah pada Peternak Sapi Potong di Kabupaten Muara Enim. Jurnal Ilmu Produksi Dan Teknologi Hasil Peternakan, 5(2), 71-77. https://journal.ipb.ac.id/index.php/ipthp/article/view/23645.

Rahmawati IR, Muksin M, Rizal R. (2016). Peran dan Kinerja Penyuluh Pertanian dalam Memberdayakan Peternak Ayam Petelur di Kabupaten Jember, Provinsi Jawa Timur. Jurnal Penyuluhan 12 (2): 183-189. https:// doi.org/10.25015/penyuluhan.v12i2.12252.

Risma. 2012. Penilaian Faktor-Faktor Risiko Pada Saat Melakakukan Pekerjaan Dengan Metode Manual Tasks Risk Assessment. Yogyakarta: Prosiding Seminar Nasional Aplikasi Sains \& Teknologi (SNAST) Periode III 3 November 2012.

Rogers, Everett M. 2003. Diffusion of Innovations (Fifth Edition). Free Press. New York.

Simamora T, A.M. Fuah, A.Atabany, Burhanuddin. 2015. Evaluasi Aspek Teknis Peternakan Sapi Perah Rakyat di Kabupaten Karo Sumatera Utara. Jurnal Imu Produksi dan Teknologi Hasil Peternakan 3 (1) 52-58. https://journal.ipb.ac.id/index.php/ipthp /article/view/10814.

Simamora T, Luik R. 2019.Kompetensi Teknis Petani dalam Berusahatani Singkong (Kasus Kelompok Mekar Tani Desa Cibanteng Kecamatan Ciampea Kabupaten Bogor). Jurnal Agribisnis Lahan Kering 4 (4) 53-55. DOI: https://doi.org/10.32938/ag.v4i4.824.

Simamora T. 2020. Peningkatan Kompetensi Peternak dan Keberlanjutan Usaha Sapi Potong di Desa Oebkim Kecamatan Bikomi Selatan Kabupaten Timor Tengah Utara. Jurnal Agribisnis Lahan Kering 5 (2) 20-23. DOI: https://doi.org/10.32938/ag.v5i2.902.

Suwarta., Irham, Hartono S. 2012. Struktur Biaya dan Pendapatan Usaha Ternak Ayam Broiler di Kabupaten Sleman. Agrika 6(1): 66 - 85. 